Greta Goetz ${ }^{*}$

https://doi.org/10.18485/analiff.2020.32.2.22

Faculty of Philology

004.738.5:378

University of Belgrade

Originalni naučni rad

Ana S. Jovanović

Primljen: 12.05.2020

Faculty of Philology

Prihvaćen: 11.08.2020

University of Belgrade

\title{
BUILDING ENVIRONING CONDITIONS FOR SYMMATHESY IN A NETWORKED PROJECT
}

This paper aims to identify some of the "environing conditions" (Dewey, 1902, also cf. 1938) discovered to enable teachers and students from a predominantly teacher-centered, non-digital learning environment to be "willing" (Wood, 1998[1986]: 175) to learn from the new experience of a networked seminar. This is to say, willing to view learning as an exercise in symmathesy (Bateson, 2015): in a "learning together" that encompasses the situation, person, tools, goals, and epistemologies and restores healthy "rigor" (Schön, 1985) to technical rationality by making it situationally dialogic and actionable in the face of complexity and uncertainty. Emphasis here is on coming to networked learning for the first time: a timely issue as it continues to be observed that the potential and experience of networked learning remains limited to a minority of courses across the globe. Although key literature in the field has established an epistemology of practice relevant in even diverse institutional contexts, existing literature lacks the "outing" of some of the difficulties faced by teachers and students. Therefore, through reflective qualitative inquiry, we engage in critical evaluation of our dialogic praxis, roles, and paradigms of growth that frames the initial problem of facing indeterminacy as an opportunity for mutual learning that embraces "real life" complexity as it moves towards strengths and away from weaknesses. This paper is thus not only relevant to "transitional" classrooms but can be further seen to be of benefit in an increasingly automatized, complex, uncertain digital landscape.

Keywords Networked learning, Qualitative research, Epistemic fluency, Dialogic inquiry, Relational teaching, Reflective Practice, Digital Learning, Higher Education.

gretzuni@fil.bg.ac.rs 


\section{INTRODUCTION}

Even teachers with decades of experience can find it uncomfortable to try new things - though the unpredictable nature of the work-world suggests that such discomfort is an unaffordable luxury. It is further unjustifiable if we can agree together with thinkers like Vygotsky (1987) that learning is an ongoing process, and if we are committed to the value of the inquisitive approach. Of course, there is something to be said for the discomfort where new situations may require a "holding environment" (Heiftez and Laurie, 2001[1997]) as teachers refine their teaching of new material, tools, and methods. But it is precisely this type of experience that offers the potential to teachers to develop a type of "Socratic skill" to make of any dialogue a teachable moment - and also like Socrates to reveal how the thinking is done, even where it reveals weaknesses. This can be illustrated by Nora Bateson's concept of symmathesy, or "learning together", which posits that due to the interconnected relationship of the living and complex world, all of the 'vitae' (organic parts of the whole) that comprise it are always learning together, forming and informing each other - towards pathology or towards health. To honor the "complexity inherent in living processes requires that we employ more rigor, not less" and "take into account the larger consequences of our 'actions' [...] to better understand the many facets of our interactions" (Bateson, 2015; also cf. Bateson, 2016). In terms of epistemic fluency, knowledge is viewed as something that can be developed, interrelated, and made actionable through reflection - which is to say that such "epistemic fluency" is more than knowing something about one field. It is also knowing what to do with knowledge and ultimately teaches us to conceive of ourselves as actively creative and consci(enci)ous contributors to and assemblers of knowledge contexts (Markauskaite and Goodyear, 2017). To see ourselves in this vital way safeguards against the reductionism and dulling of our human potential suggested by certain technological interfaces today (Norman, 2011) as well as reductionist and mechanistic thinking (Bateson, 2015).

By engaging in a qualitative inquiry that focuses on a case study of a networked seminar, we seek to critically reflect on our attempt to heal the discomfort of leading a networked course for the first time in an otherwise teacher-centered environment which hides the process of learning and 
BUILDING ENVIRONING CONDITIONS FOR SYMMATHESY ...

presents it only as a final destination. In doing this, we use critical pedagogy as a tool for creating a deep understanding of the educational processes and relational conditions of empowerment. We also seek out the transformative potential of research where it promotes emancipatory consciousness (Kinchloe et al., 2018: 421). Behind our work lies our intention to cultivate empathetic responses, interdependence, and care about relationships, and move away from shadows and towards strengths (Vivian and Hormann, 2013; cf. also Anderson et al. 2020). Through entertaining the larger social and technical views and expectations of education, we seek to experience with our students the ultimate "iterative" meaning of knowledge. What gives us pause for thought is how, in the initial stages when shifting to a design environment that focuses on epistemic fluency or symmathesy, it is so hard to believe we are making progress.

\section{BACKGROUND}

The newness that has characterized the last decade has involved the ubiquity of digital communication. Digital technology permeates even classrooms where it is banned by affecting what happens before and after class and engagement during class (Fawns, 2019: 133, 142). This cannot be understated even where it cannot be claimed that its ubiquity has changed students' demands of the classroom (Jones, 2012: 37). Despite the prevalence of technology outside of the classroom, the percentage of courses making use of digital learning remains low (Hodgson and McConnell, 2019; Online Learning Consortium, 2017). This is troubling because a digital divide is emerging, separating those who are digitally literate from those who are not. It also has the potential to lead to classes of people who are mere users and not co-creators of technology (cf. Norman, 2011), meaning that there are cultural and epistemic implications to this divide. When changes are effected through technoscientific and neoliberal advances, those countries or people who have gone through all phases of the transformations themselves are in better positions to critique them than those who have not. Some cultural milieus end up in positions of forced adoption, stripped of the experience of having time to develop mechanisms for critique (Ricoeur, 1991: 190-191).

It is conceded that, like Aristotle's "exoteric" lectures (Ross, 1952: 5-6) and Deweyean pragmatism, engagement with change and 
dialogic engagement outside the walls of an educational institution can be understood as an "additional", fundamental element of education supplementing historical expertise. But while such an apologia may be warranted in a teacher-centered setting, it must be acknowledged that the gap between institutions that do not recognize the decades' old need to develop critical, reflective rationality and artistic "rigor" (Schön, 1985) where it teaches an epistemology of practice in indeterminate zones will produce students unprepared for the present day. Most institutions of higher education strive to change and improve but may face a number of barriers in the process, some of them related to the need to "include changes in mindsets that can lead to action" (Kezar and Holcombe, 2019: 3). Yet, these changes are essential because individuals who are not autonomous and lack relational skills will not be in positions to make creative contributions to the larger social whole. The promise of "cognitive democracy" is that such contributions are possible. Edgar Morin explains how potentially antagonistic mutual relations, interactions, and implications at once nourish cognitive democracy while democracy in turn regulates them. But, he continues, such democracy is threatened by the technoscientific, where it is reductionist (2008[2004]). Digital literacy can thus be understood as involving a "calibration" (Bateson, 2015) of sensitive actionability in the face of neoliberal technoscientific complexity and uncertainty. Such calibration will not be possible for the digitally illiterate.

\section{From Constructivist to Networked (Digital) Design}

It is emphasized that professional competence requires exposure to different knowledge building practices, or "epistemic fluency" (Markauskaite and Goodyear, 2017), which can be understood as the ultimate skill set and tools that a course in networked learning seeks to promote: the ability to interact constructively with the ever more complex world. It is in this respect that networked learning can be seen to address the digital or "postdigital" landscape - the latter being the term of choice among some to "encourage a more critical stance towards understanding technology in education" (Fawns, 2019: 142). While there are many terms used to address the use of technology in the classroom (e-learning, digital teaching, technology enhanced learning, to list a few), the term used in this paper is "networked learning" to address the "augmentative" (Engelbart, 2002) or "complementary" (Krakauer, 2016) potential of 
digital communication. The term draws attention to the goals underlying the field of networked learning, such as critical pedagogy (cf. Freire, 1970; Giroux, 1992) and democratic and experiential learning (cf. Dewey, 1916; Kolb et al., 1974), as underlined in Hodgson and McConnell (2019: 44). The tradition of this critical approach allows for both the use and criticism of new digital technologies (in other words, allows for digital literacy), and further provides alternate approaches to the endeavor to make "good" and symmathesic sense of the contemporary world as suggested in the introduction (cf. Gardner in Goetz pending).

While technology offers new opportunities for learning in terms of information availability and exchange, the potential for greater democratic access, epistemic revelations, and so forth, "[g]rafting on technological advances does nothing to mitigate [the] need for maturity in formal learning environments" (Beaty et al., 2010: 590). In the words of a more recent work: "What was stressed in this early work and definitions of networked learning was not how technology could change or enhance learning but the way new connections that technology was materially offering to staff and learners alike could assist and extend important pedagogical thinking and ideas" (Hodgson and McConnell, 2019: 45). We will consider this in terms of Bateson's word "symmathesy" to stress the interdependence of the features of the networked learning environment. The word is further suggestive in this context as we take her point that in the fields that have sought to learn how we learn that emerged from cybernetics, the vocabulary that frames our understanding is too mechanical and can pretend to a mastery that is unrealistic. Through symmathesy, we are also reminded of the organic nature of life, replete with its stages and own models of growth. This model can embolden those who dare to begin the unexpected - which can be challenging even where this 'unexpected' is mitigated through design.

\section{Joint Inquiry through (cycles of) reflective dialogue}

Dialogue is a central aspect to networked learning (Beaty et al., 2002; Hodgson and McConnell, 2018) as it is the means through which the reflective relational knowledge-building and assembling takes place (cf. Lave and Wenger, 1991). Socrates models an approach to discursive techniques of critical thinking, which can be described as "joint inquiry with me" (Plato, 1967a: 84c). Plato contrasts this with the approach of 
the sophists who, like Protagoras, treated knowledge as something that could be downloaded (Plato 1967b: 312). In the context of relational and symmathesic learning that sees learning as so much more than (though definitely comprised of) 'vitae' (Bateson, 2015) of knowledge, these sophists appear less as teachers than those who serve a cautionary tale about 'teaching'. The antidote to that "is to stop viewing knowledge as a thing - an item that can be possessed, contained, bartered, or sold and instead to view it as a process" (Lissack, 2000: 87). The question remains how to give potential learners the assistance they need to find "out the truth of the matter: for now [they] will push on in the search gladly" (Plato, 1967a: 84b). This is why the course in question sought to model active research/learning cycles: to ensure that guided questioning was integral to the course.

In the dynamism of networked learning environments, individual and collaborative dialogic reflection cycles interspersing periods of action are a valuable means by which to evaluate the quality of the learning, adjust for changes if necessary, and instill effective practice for reflection in students' lifelong learning (Sorensen, 2010). These involve higher order cognitive processes through which we analyze and make sense of past or ongoing experiences, which then influence our future choices and actions (Reynolds, 2011: 5). But this is also an affective process, because our cognition is always supported or hindered by our emotions, fears, motivations (e.g., Damasio, 1994). Understanding all these factors and the ways in which they are intertwined and rooted in different contexts and situations is genuinely empowering because it has an emancipatory potential. For example, by bringing our whole selves to a situation and consciously engaging with it through reflective situational dialogue (Schön, 1985) we have an opportunity (whether it is taken or not) to see the consequences of our "learned" pathologies (cf. Bateson, 2015). Joint holistic empowerment would seek to free us from these and cultivate our strengths in all respects, and not spare criticism even of the teacher's role. For it may have its own pathologies, though we recognize its good intent.

Drawing on actor network theory and psychological dynamics, Perriton and Reynolds suggest substituting the "pedagogical self", which tends to define and prescribe, with collaborative pedagogies based on inquisitiveness: in this way, teachers can become more inquisitive and less value laden (2014: 124). But some students may wish for such "pedagogical 
selves" and "hope for or expect that teachers will fill their knowledge gap by presenting a digested version of the literature" (Levinsen and Nielsen, 2012: 240). Instead of providing this "digested knowledge", teachers may respond to their students' needs by providing care and support (Noddings, 2012) and assisting them, in this way, to become self-initiated and creative individuals. This can be particularly true of students used to taking the more passive role in learning that is characteristic of teacher-centered educational models.

Reflection cycles, as a feature of this collaborative approach, may assist learners in creating metadata which "makes it possible not only to navigate through data, but also to link them and thus to trace within information the circuits that transform this information into knowledge" (Stiegler, 2011: 33). This moment-to-moment theorizing, data collecting, and inquiry that emerges in the midst of holistic, genuine interactions is at the core of knowledge created outside circles that claim to know the answers (Lewin, 1946: 42).

\section{The mentor as architect}

While the constructivist shift - today referred to as relational education, where education places learners in contexts designed to make actionable the relations between themselves, others, resources, tasks, situation - describes the facilitator more as an "architect" vs. contentprovider, fellow learner vs. dominator of the teaching (Goodyear, 2001: 140-142, 46; also cf. DiSalvo et al., 2017), this does not preclude the teacher's pedagogical, managerial, and social role (Collins and Berge, 1996). Dewey himself warned that the learner's "experience" is not to eclipse "guidance and control" (1902: 10,11). Teaching thus becomes a problem of maieutics, according to which the teacher adopts the role of mid-wife involved in a dialogic process. As such, the teacher must be more than academically competent and be able to interpret students' ZPD and anticipate their needs (Goodyear, 2001: 263): acting at once as process supervisor, social mediator, and expert "depending on the phases of the project work and the situational mood among students" (Nielsen and Danielsen, 2012: 266). Wood calls this "contingent teaching" noting that "it is difficult to teach [...] contingently all the time" (1998: 164).

If a practically oriented task is set in a networked-learning environment, additional challenges can arise. Just like in the Socratic 
dialogues, each new course - despite having the same environing conditions - will have its own, unique dynamics as well as unique needs in terms of what is required of its teachers or facilitators. This resonates with Bateson's concept of symmathesy, which she describes as "contextual mutual learning through interaction" (2015). Because the learning is taking place on so many levels in the networked environment, networked learning requires additional expertise on the part of teachers (cf. Beaty et al., 2010: 590). In this respect, the teachers may be considered as "animators" whose role is to encourage communication, the integration of multiple views, and "the reification of network activity into products of one kind or another" (Jones and Esnault, 2004). The role of the mentor, or animator, is thus to build autonomy: keeping options open and merely facilitating the process. Like in the story of Goldilocks and the three bears, the animator's role is to be 'just right', guiding the learner from where they are to where they want to be (Knowles, 1984).

There is no doubt that active engagement in the collaborative construction of knowledge is a core quality and a necessary prerequisite for the development of epistemic fluency, which is, after all, learning how to learn how to do things with other people in diverse contexts. However, the question could be raised as to whether all students see their active participation as their responsibility. It follows that networked learning also requires additional expertise on the part of participants, whose awareness of the responsibility, privilege, and value of such learning opportunities must somehow be cultivated both through practical exercise and dialogue.

\section{METHODOLOGY}

Our research aligns with the postulates of qualitative inquiry where it is understood as interpretative, participatory, critical practice, "an interactive process shaped by one's personal history, biography, gender, social class, race, and ethnicity and those of the people in the setting" (Denzin and Lincoln, 2018: 45). The concept of conscientizacao used by Freire (1970) is central to this inquisitive approach, which penetrates beyond how the educational context appears. This is to say that a course is never just good or bad, successful or a failure: there are myriads of factors that determine the outcomes of the educational decisions of each of the participants in the learning/teaching process. Understanding these factors - through 
BUILDING ENVIRONING CONDITIONS FOR SYMMATHESY ...

participatory research conducted by both teachers and students - is what enables participants to grow, "but also provides space for inherent change of course and maturation during the research process itself" (Filipović, 2015: 13). It could be said, then, that the main goal of this inquiry is to illuminate "constructed meanings (understandings) within a specific social context, from multiple points of view (Greene, 2000), with the goal of reaching better understandings of shared experiences" (Levy, 2004: 49). In other words, where the objective is to reach better understandings of shared experiences, the framework of the seminar - in which knowledge is posited to arise "through a process of active construction" (Mascolo and Fischer, 2005: 49) - is at once the subject and the objective.

The specific strategies used in this inquiry are thus to be seen as an extension of the dialogic learning approaches: by externalizing knowledge through different methods of analysis and reflection, the participants reach a new level of awareness that is at the core of critical thinking and metacognitive knowledge (Jovanović, 2016: 40; cf. Paavola, Lipponen and Hakkarainen, 2004). Such focused metacognitive reflection supports the academic maturation of the participants - students and teachers alike - and offers a deeper understanding of the dynamics of the educational phenomenon. This was our experience through the qualitative inquiry of the bilateral networked seminar, presented in the sections that follow. First, we give a brief overview of the networked course in question. Next, we introduce autoethnographic methodology in order "to explore the double-bind of its particular awareness and engagement with the Other" (Spry, 2018: 1094). Finally, we introduce students' voices through the data obtained through reflective interviews as yet another tool for the coconstruction of knowledge.

\section{The Networked Seminar}

The focus of this paper is a case study of a unique, bilateral, networked pilot seminar, consisting of graduate students at the University of Belgrade collaborating with undergraduates at a United States public university under the umbrella of the Trans-Atlantic Pacific Project (TAPP) (cf. Mousten et al., 2018). The task of this networked collaboration was the elaboration of a grant proposal as a response to an actual call envisaged to better the lives of a target group. The design of the learning environment thus comprised very diverse groups of participants: 36 undergraduates 
from the US and $12 \mathrm{PhD}$ students from the capital city in Serbia as well as their teachers. Two students from Belgrade were teamed up with five or six students from the US and their activities were monitored by teachers on both sides of the ocean. The design was an elaboration of the collaborative configuration characteristic of networked learning: "between one learner and other learners; between learners and tutors; between a learning community and its learning resources" (Goodyear et al., 2005: 473). The project-based course, conducted in the fall semester of 2017, was listed as an Independent Research Study seminar in Belgrade, aiming to elicit selfdirection and epistemic fluency. To this end, the Serbian instructors sought to evaluate their role as facilitators: attempting to "foster and promote" (Jackson, 2004) the shared activity of the networked environment, providing mostly higher-order guidance, encouraging an awareness of how knowledge is created and disseminated in a networked environment. This guidance focused mostly on dialogic methods of inquiry and cogent expository techniques and prompts related to higher-order skills (e.g. Wells, 1999) that we mainly introduced during periodic meetings. Additionally, the students were asked to write short reflection papers addressing the features and progress of their networked communication. More specific methodological issues were not imposed but emerged as student needs arose, and were brought to full articulation through the interviews held with six of the students after the course was completed.

\section{Autoethnographic Accounts}

We consider autoethnography to be a facet of co-creation, critical reflexivity, and shared responsibility for learning as it involves the critical engagement of the teacher(s) with or among themselves with the aim to promote a more holistic experience of co-creation. Acknowledging our own "visibility" (Bruni, 2002: 24) in the design reflected on in this paper is an attempt to make ourselves intelligible to ourselves and to others (Butler, 2005: 21). We took a partial collaborative approach to this autoethnography (Reed-Danahay, 1997) as there was more than one of us and we considered such an approach to align with the general direction of the principles of symmathesy. Furthermore, by including this layer of research here, we hope to produce a more Geertzian "thick" description of our networked learning experience as we also wish to highlight some of the particulars of our specific culture. 
A practice in rigor: bracing for the unknown

While I expressed clearly that I could not recommend myself to coteach a networked course as I had never taught one before, I was very excited by the opportunity even though I had not previously known any of my co-teachers - and was honored to be included as a 'local' but also a native English speaker (raised in Asia, educated in the US and Europe). Digital literacy is already a component in my own courses, though I also work on maintaining the slow humanistic work of the philological tradition.

In this course I mainly focused on the reflective and relational aspects of epistemic fluency, providing question-asking scripts and having students model for each other the progress of their work or articulate the obstacles that they were facing. Parallel to that, I was also articulating my own experience of class in emails to my co-teachers. This has been covered elsewhere in a pending coauthored paper, but here I would like to acknowledge how often my colleagues and I talked about scaffolding, specifically, whether we were giving enough of it.

I can describe this problem in terms of a platitude of higher order learning: if it is not possible to master the "meta" then one can drop back down to the component elements and practice each of them in isolation, which is to say, adopt a Vygotskian approach to ZPD where it contains constraints and affordances. But how often to do this stymied us.

This type of project is not "first order perspective learning" which positions the teacher as the main designer, leading the learning as the main source of knowledge while denying the student an intrinsic capacity for learning. In the second order perspective, the teacher is still the main creator of environmental conditions but the teaching is facilitation of student learning-by-doing. In the third order perspective, teaching is coconfiguration: learning by consci(enci)ous inhabiting (Markauskaite and Goodyear, 2017). In the case of the networked course in question, I taught it as if it was third order, when really it was between third and second.

What this means practically is that in addition to having designed an authentic inquiry environment with prompts and scripts, guiding students' own mutual exchange to illustrate best practice (as one team was effectively modeling epistemic agency), discussing evidence for or against certain decisions about practice and the task at hand, I should have made the characteristic moves of the game explicit and illustrated the method during key cycles of our design. This would help prompt thinking through 
a situation or a decision "as" an expert. I could have further provided external representations of some of the steps involved, like by providing graphs. That was how one of our student groups resolved their own uncertainties: replacing the literature they had explaining their task with a graph they found online illustrating the task's major steps.

I only came to this realization after the fact; during the process, while I knew students wanted more, I thought that they were capable of learning how to learn how to find what they needed. Some groups, as indicated above, did do this - but did not necessarily understand their "moves" as successful.

What I think confused things for me is that at the second and third order perspective of learning, intuition is what relates the different ways of knowing and knowledge to the situation and people, so can be hard to talk about. What we are looking for as teachers is whether the intuition has been activated correctly: correctly coordinating an understanding of the nature and sources of knowledge and epistemological activities, models, and stances (like belief and doubt) (cf. Markauskaite and Goodyear, 2017: 531). The epistemology of practice that calls on knowledge to relate people and resources in an uncertain situation lies somewhat beyond technical rationality (Schön, 1985: 26; Dewey, 1916: 27) and cannot be taught (cf. Aristotelian phronesis). So while the rules or moves of the game are integral to this intuition (Markauskaite and Goodyear, 2017: 396), there comes a moment when we need to be given an experience, in practice, to see whether we possess the necessary intuitions to assemble and use relevant knowledge. Epistemic agency is tricky. So I would describe our competence as teachers as being our commitment to the design of a genuine inquisitive environment. The emphasis on the genuine (cf. Lewin, 1946) is important in that it allowed us, together with our students, to find ourselves in a space of uncertainty, which led to the productive sometimes uncomfortable knowledge of this paper.

The question of expertise is raised here in the same way that it is modeled in Plato: when Socrates' interlocutors are given the last word. But Socrates retains his expertise in prompting us to think. He keeps open authentic inquisitive spaces, even where he 'fails'. This 'reality' is supported by a foundational work in networked learning that provides a methodology even for cases where students have more of one kind of knowledge than their teacher (Goodyear, 2001). I think there is value 
in walking through this thinking as this is where much doubt lies and acknowledging it defends for our students an experience that some of them can be too afraid to have if it momentarily appears too overwhelming. That can be contagious and something to guard against in early days. Also, this approach runs counter to the implication of the systems theory to have emerged out of cybernetics that we can learn how we learn perfectly and we are to eliminate anything that resembles error or imperfection (one strain of cybernetics indeed seeks to replace the human). And this is where I value Bateson's symmathesy for it does not presume to reach full control, nor does it strive to - but it does insist on a challenging rigor. This is the same word used by Schön.

How effective is teaching epistemic fluency if it does not teach coping mechanisms for when we are met by complexity or shortcomings? After all, we are teaching students to deal with the real, complex world as it is. Bateson asks whether the myriad interactions within and between the living systems of this complex world must necessarily be a hindrance: might this "rigor" instead be "the next frontier of inquiry?" Venturing into such "indeterminate zones" requires a leap of faith, by which I mean a belief in the meaning of creation even when it does not look like it is getting anywhere. Rigor pushes through this uncertainty - but rigor is afforded through the opportunity to demonstrate it. Design can be this opportunity, and yes, that is what I was saying to our situation. "You can be our opportunity, come on now." Even after the fact - relating that situation to new ones.

\section{A leap of faith}

In August 2017, I received an invitation to take part in a networked course that would involve students from two institutions of higher education: the University of Belgrade, where I had been accepted as an associate professor only a year before, and a public university in the US. The invitation came through an e-mail from a professor from the University of Belgrade, a person I consider my academic mother due to her continuous guidance, presence, and support in my professional growth. Moreover, she was the one who strongly encouraged me to complete my master's and doctoral studies at a public university in the United States, an experience that critically marks my professional identity as hybrid. Hence, an invitation coming from her - with its tacit promise of challenge, 
innovation, and growth - was the deciding factor in my positive response. I did have concerns about participating: on the one hand, I was worried about the amount of time I would be able to dedicate to this project due to a number of other responsibilities I needed to juggle as a new and relatively young faculty member. On the other, I was even more apprehensive of the fact that this would be my first networked learning project. Although I have a background in sociocultural theory, holistic learning, and critical pedagogy, my experience with networked learning was only tangential and, consequently, insufficient. Naturally, I was worried about this weakness and the fact that I might not be able to live up to the challenge of the networked project, a feeling that was compounded by my awareness that it involved an international collaboration. Thus, any of my inadequacies would not be confined to the limits of our local educational context; rather, I would be exposed in front of an international community. I made a conscious effort to rationalize these concerns and to remind myself that there is no learning without stepping out of the comfort zone; there is no learning without dedication, exposure, and critical self-evaluation. The fact that I didn't question for even a moment whether I possessed the necessary qualifications for this project, now, in retrospect, tells me a lot about my lack of awareness of the complexity of networked learning, but is even more revealing of my (uncritical) confidence in my mentor's authority. I was completely assured by her judgment of my capacity to learn along the way. Additionally, I knew that I wouldn't be alone in this process because this would be a teaching endeavor shared among three teachers. I expected - rightly, as it turned out - that any difficulties that might arise could be solved by the collaborative effort of all of the teachers who together would be able to provide mutual guidance and support. It was far from comfortable, but I was able to make this leap of faith.

Considering the fact that the students on this side of the ocean were already at the doctoral level, I assumed that at this advanced stage of their education they would be quite autonomous in their engagement with the task: the design of a project proposal through networked collaboration. This was further supported through communication with my mentor and the idea of heterarchic principles of distributed responsibility (Stark, 2001) which posit that knowledge is created through full participation in communities of practice that foster relationships of good-will, trust, and shared responsibility. On the other hand, I was very much aware of 
the educational model still dominant in the local context, predominantly teacher-centered and, consequently, marked by a traditional student/ teacher role division (cf. Jovanović, 2016): the teacher's task is to provide instruction and the student's is to follow and acquire. However, the design of our networked project was all to the contrary. The set-up was highly student-centered with a task that clearly required students' direct engagement and collaboration in a networked setting. Consequently, we envisaged that one of the main outcomes, in addition to specific project proposals, would be related to students' enhanced sense of autonomy and epistemic fluency. Naturally, for this to be possible, it was crucial that the students be willing to take a leap of faith, to believe - as I believed my mentor - that they would be able to complete such a demanding task and to actually grow in the midst of their feelings of discomfort and insecurity.

My main preoccupation throughout the course was to create just enough scaffolding for the students so that they would feel empowered but, at the same time, free to pursue their own goals. Nevertheless, our students' occasional comments, sprinkled shyly through correspondence and seminar meetings, kept me alert of our students' wish for more explicit instruction. A few times I even sensed a sort of resentment on their part, probably coming from their impression that we were not providing them sufficient instruction and supervision. While they wanted precise guidelines, we were asking them to establish their own goals and to arrive at the best way to reach them. Not only was this an uncomfortable position for our students, but for me as well since I have a strong need to respond to other peoples' needs - a personal trait that could be a sign of empathy or insecurity, one can only surmise... It was thus my main goal to compensate for these mutual feelings of discomfort by giving ample feedback and encouragement, by reflecting together, through dialogue, on the critical features of the task - both positive and negative - and by making explicit the students' protagonism in the learning process. This implied looking for interfaces (cf. Bateson, 2015), identifying our boundaries as the place of symmathesy, acknowledging our shared responsibility for the learning process. For me, this meant remembering Noddings's explanation of the word "response-ability": being able to respond (Murphy, 2013); getting to know my students and being able to identify how much autonomy each of them was capable of adopting. For students, this mainly implied acknowledging the unique strengths and weaknesses that help them in 
- or keep them from - 'taking over' their responsibility for the learning process and successful learning outcomes. It was unsettling to me that, while most students were completing subtasks more than adequately, their feelings of self-doubt were palpable; moreover, their success was more than once attributed to a lucky coincidence (good team, good timing, good communication, and such). For this reason, I needed to emphasize the positive aspects of the students' engagement and try to control their level of frustration by converting the perception of success into a sense of accomplishment. I needed them to see that their success was not the result of chance, but the consequence of their conscious, well-managed dedication to the collaborative project. In a predominantly teachercentered educational system like ours, where success is frequently related to obtaining a high grade for a specific task set by the professor, one that usually implies the straightforward, uncritical acquisition of knowledge, it is not an easy task to accept that a person may actually be the demiurge of their own learning. Hence, the collaborative project-based seminar turned into an exercise in self-confidence: accepting responsibility and acknowledging personal strengths and capacities for relational learning with other people, places, things, and technologies.

\section{Reflective Interviews}

The aim of the reflective interview conducted at the end of the learning/teaching cycle was to co-reflect with students on their understanding and interpretation of key aspects of the networked course (Klein, 2002; Sorensen, 2010: 571; Markauskaite and Goodyear, 2017: 593). Like the qualitative research interview, the reflective interview was a "construction site for knowledge" (Kvale, 2007) that supported the ethos of the course, following the Socratic directive of "joint inquiry". We used in-depth interviews that were largely unstructured although a set of themes with tentative questions were formulated in advance. These revolved around several topics of interest: students' expectations and motivations for choosing the course, their perception of the different aspects of the learning process (e.g., tasks, group collaboration, student and teacher roles, the cross-cultural and digital network), and their understanding of the symmathesic interrelation of these aspects. Half of the students from the University of Belgrade who took part in the seminar agreed to be interviewed. After obtaining their consent, interviews were conducted 
by two teachers, the authors of this paper, primarily in English but in Serbian where clarification was needed, and were audio-recorded while some additional notes were made; we transcribed complete interviews for further analysis. In order to find and interpret themes that cut across cases, we used a variable-oriented strategy as proposed by Huberman and Miles (1998). In the following sections, we present the data from the reflective interviews that elucidate some of the key concepts addressed in the previous sections of the paper.

The novelty of the networked approach:

finding strength in (real life) uncertainty

Our participants expressed that their interest in the course was sparked by its novelty. It was "the American approach (TK, initials), "a more practical approach to doctoral studies at this faculty; we mostly deal with theory, literature and language, but not as much with practical or corporate application of the language that we study" (SA). Key words reiterated in all of the interviews are: applicable, practical, real, life-like - all of which, incidentally, are applicable to the notion of apprenticeship, a focus of Jean Lave and Étienne Wenger's seminal work on learning as active participation in the practices of social communities. Such learning does not precede doing, nor is it a condition for doing; instead, it happens while being involved in the task. One participant recognized how the practical experience of real life is slower, and involves a learning curve:

[to] do and learn instead of just reading and then applying that, [involves] trial and error [...] it is possibly a bit slower, painstaking at times because you do have to invest a lot of time because you have to produce something, but I think it's more effective because then you remember more about your past errors and about how your work has evolved in that practical sense (SA)

As the main course objective was to write a grant proposal, it stands to follow that the course could be viewed primarily as an exercise in the application of practical skills (and skills, by that token, that were not new to the students, who have had experience in creative, professional, and academic writing). However, the lack of the more traditional lecture format, where knowledge is delivered by a teacher, underlined the fact that knowledge was not going to be "handed over" in this course, but needed 
to be created through a series of steps. What was new to this approach was therefore not the nature of the task - to compose a written product, as demanding as that may be - but the process of having to accomplish this in a networked environment, requiring students to relate themselves to others, sources of knowledge, digital tools, and the situation. In fact, most of our participants had little if any experience in basic teamwork and saw this project as an opportunity to take part in the process of collaborative learning: "so working with people that we have never seen or heard before, and many people, not just like two, two by two, but there were quite more people than we expected" (JS).

Finding themselves faced with new people in what was an entirely unfamiliar situation naturally introduced a sense of insecurity among our students. This was compounded by their uncertainty over what their roles and tasks should be. Thus, even where our respondents recognized a need for leadership, and saw themselves in the leadership role because of their age and study level, they did not necessarily know what to do with this new-found responsibility as they had rarely been called upon to exercise relational skills:

I have a feeling that there is a great difference between pre-graduate studies and $\mathrm{PhD}$ studies, it's in the expectations of students; so, you know, till one moment you're used to 'this must be done; I chewed it up for you and do it like that', very instructive, very precise, very narrow and limited in a way; and here you have the liberty to much greater extent and you don't know what to do with it (TK)

It appeared difficult for students to become pro-active in the learning process since, prior to this point, they had largely been taught to follow the teacher's lead; to act as instructed, when instructed. Without putting it in so many words, they recognized the limitation in coming to a networked project from a teacher-centered background:

even at the $\mathrm{PhD}$ level we still have classes where teachers, like, apart from giving you the literature, they still go through that literature and explain everything to you, and then it's up to you to read, to, you know, go deep into that and again ask questions (EP)

Therefore, a teacher-centered background can be seen as an impediment to self-direction and symmathesy. In fact, respondents pointed 
BUILDING ENVIRONING CONDITIONS FOR SYMMATHESY ...

to the mismatch between the teacher-centered educational model that had formed them and the networked, project-based approach. At the same time, they were aware of how the success of the new environment depended on their contribution to it and the degree to which they were able to mitigate the "unknowns" of the networked environment through good communication and learner autonomy. According to one of the participants, the networked, interactive aspect of the course provided the overarching structure of the learning environment:

we were expected to make a project, seven people, five people from a different continent and two other people from this continent, two people from Europe and five people from the US, and it needed to look cohesive, of course; so, we all needed to learn something; it is only, it can only be done through controlling and having an insight on, into other people's work at all times (JZ)

This participant's "relational awareness" also included awareness of the symmathesic role of digital technology:

Google Docs was very beneficial for everyone; we chose to do it so that everyone had a task, each member had a task, and then when it was all finished, everyone could comment, of course (JZ)

All participants acknowledged shared responsibility for the outcome of the collaboration and adopted various techniques for managing the interactions that went into the co-creation of knowledge. To give one illustration, a successful strategy for creating cohesive text, which was used by some of our participants, was to edit and evaluate each of the contributions made by other team members: "the editing was excellent; so, first of all, [JS] and I edited each other's work and then we sent our work to our colleagues, and then they sent it back, so we always got that feedback from them" (TS). Such networked feedback is valuable in terms of its role in the collaborative activity but it is also important to developing the relational skills that mark the beginnings of assembling and inhabiting democratic epistemic environments. They are not only performing a task, but articulating it with an eye to best practices.

Becoming self-directed

Individuals who excel on the battlefield between the teacher-centered positivist and student-centered constructivist academic approaches are 
able to take on a leadership role, understanding the responsibility of their agency in the learning process. However, not all students are sure whether this should be their task, as we can observe in the following comment by TS. Here, in describing her perception of students' roles in a networked course, she begins to speak on behalf of all of the students from the teachercentered background, referring to herself together with them in the third person:

it wasn't clear enough ... that they were supposed to fully monitor the language use, that they should be involved in language monitoring and writing proposal and organization, you know, a mismatch, a mixture of everything; but if you ask the girl from organizational sciences [another student], they understood the task totally this way, they understood that they should just monitor the entire process, control it in a way and just [act as managers] (TS)

Most students need some guidance (cf. Nielsen and Danielsen, 2012) and individuals that lack autonomy are not able to engage effectively with the networked environment, but a positive effect of a collaborative digital networked environment is that it necessarily promotes awareness of this lack of agency. One individual who felt she lacked agency argues on initial reflection that this was due to a want of tailored feedback and modeling:

maybe feedback is the toughest part, because, you know, you can explain [to] someone theoretically as much as you want, until that person starts writing it actually and, you know, the point when you see something written on the paper, that's when you see whether you explained it well or not; it's like when I do it with my students for writing essays, I can tell them ten times that they need something general, but the point when I say 'okay, guys, we have this topic, right? you talked about, whatever, [...] I want to show you how out of what you have, like, not giving you my own idea, but out of your idea, how to shape your idea and then, like, okay, now I'm giving you to play with that, and then, get to know what is actually your task (JZ)

And yet, when prompted to reflect further, this same participant recognizes that a greater learning experience can be had when students are allowed to see the results and consequences of their approach. This 
BUILDING ENVIRONING CONDITIONS FOR SYMMATHESY ...

suggests that the plea for more modeling and more feedback may be an expression of insecurity:

sometimes it doesn't matter how clear objectives you set; it's like with, I mean, I now see that with my students, so no matter how clearly I explain that to them, only when they, you know, make a lot of mistakes do they realize 'oh, that's what you were talking about', you know; just in every process learning that's the way it goes, you know, you can't really, you can't really explain it to that extent that everyone like captured it immediately, but first has to go through that in order to know; when I saw that proposal and everything set up, I was like 'aha', sort of that state of mind (JZ)

This passage underlines the importance of "actionable" knowledge to epistemic fluency (Markauskaite and Goodyear, 2017): unless a person goes through the whole process, unless they live the process, we cannot assume that they understand how they can accomplish what they are expected to do. In this respect, too much guidance may hinder autonomy a point that was not lost on students: "people shouldn't hijack the process, shouldn't put students into a situation they're uncomfortable in; so, give as much support to them in their chosen project in the chosen process" (SA). This student insists that features and problematic aspects of the task be pointed out, while only minimal support is lent to students so they may find the right solution on their own, through dialogue and studentgenerated modeling (as they discuss and analyze their project development in the action research cycles).

Interestingly, even though all the students in the pilot course were able to complete the task successfully or in some cases even master the task, all participants (even the one cited above) expressed in the postcourse interview a wish for more guidance at different levels. While we all agree that a tool for guiding the students through this process is feedback - "feedback is the moment when you actually do that clearing up" (EP), the nature and timing of this feedback can be hard to get right. But getting it right is crucial to participants' views and experiences of themselves as creative participants in a symmathesy that better matches their needs, expectations, and interests the more they develop their literacies, relational skills, and agency as promised by the premise of cognitive democracy. 


\section{Different takeaways}

Not surprisingly, then, our students emphasized very diverse takeaways: a "sense of satisfaction" gained from completing the project (EP); a better understanding of the networked problem-based learning: "it broadened our horizons, that's for sure, we saw that it was a complicated process and you cannot do it overnight" (TS); a new experience in "how actually to leave my comfort zone and be more assertive in suggesting my proposals and making a statement, presenting my own opinion" (SA); a wake-up call for the need to become autonomous: "the system definitely differs; that's my impression; you gotta snap out of it and start working on your own" (TK). EP, the student who demonstrated the highest level of autonomy was in fact the only participant who explicitly identified the course objective - the development of grant proposal writing skills - when asked about the main takeaways. This may indicate that the level of autonomy strongly influences the level to which students will be able to reach the course objectives set in a dialogic networked learning environment. That said, we need to underline again that all participants did fulfill the course objectives. Where they differed was in terms of their perception of the outcomes - to the extent that some students even attribute success to luck: "success, you can blame it, I mean 'blame it' on good communication, combination of characters, combination of people" (TK). This comment lacks awareness of the interaction of those factors: it is precisely due to the "good communication, combination of characters, combination of people" that this team was successful. Unfortunately, even after the reflective interview, this student is not willing or able to acknowledge her part in the accomplishment of the project. In this specific case, even the reflective dialogue failed to help this student recognize the accomplishment she was able to make in collaboration with her team.

The reflective interviews played an important part in bringing to our attention key elements of networked learning, such as our respective understandings of shared responsibilities, interdependency, and rigor. In specific cases (e.g. JZ), the reflective dialogue facilitated the externalization of tacit beliefs, which had hindered the development of autonomy due to an overdependence on teacher guidance. On the other hand, in some instances, neither the seminar nor the reflective interview were powerful enough to provoke a critical awareness of stances and attitudes. Such was the case of TK who kept insisting that the value of her team's success was due to a 
BUILDING ENVIRONING CONDITIONS FOR SYMMATHESY ...

lucky coincidence. Evidently, a single experience in networked learning, as successful as it may be, does not have the potential to change deeply rooted epistemological beliefs developed throughout a person's education. For this reason, students ought to be exposed to multiple, different courses that all seek to promote epistemic fluency (Goodyear and Zenios, 2007; Perriton and Reynolds, 2014).

\section{CONCLUSION}

Coming to a networked learning project for the first time involves a learning process that is at once expected and unexpected. Seeing this opportunity as an example of symmathesy, an opportunity to learn together, theoretically distributes the responsibility among all participants and shifts teachers' expertise to their ability to design environing conditions that prompt dialogue that seeks out the same kinds of knowledge that would ordinarily be 'delivered' in the teacher-centered classroom. But in practice, a more hands on approach may be required. Rephrasing shadows in terms of opportunities for building strength can prove to be helpful. Our experience was mixed: we felt we could have provided more scaffolding, but at the same time, recognized that ceding our "pedagogical selves" to the inquisitive environment provided a critical learning experience for our students, whose own dialogues cited here demonstrate how much they learned - even though this might not have been immediately apparent to them.

Practical experience is also needed for teachers, and to make this practice "visible" we included autoethnographic accounts in this paper. With their potential to re-live the holistic experience of ourselves in relation to our students, colleagues, situations and tools, we were able to raise awareness of issues of agency, responsibility, and educational theories. This further assisted us in assessing the needs of the "environing conditions" of interaction and activity:

Organic interaction becomes inquiry when existential consequences are anticipated; when environing conditions are examined with reference to their potentialities; and when responsive activities are selected and ordered with reference to actualization of some of the potentialities, rather than others, in a final existential situation. (Dewey, 1938: 107) 
The organic interaction of experience is what makes knowledge actionable and action knowledgeable. Yet, as Dewey explains and in another work states explicitly, practical activity alone is not enough for there to be learning - there must, first and foremost, be that which functions to "start and guide thought" (Dewey, 1902: 18). This may be found in the reflective element of inquiry and, taking a cue from Schön, in answering technical rationality by questioning ends instead of refining means (1983: 39).

It could be argued that the very nature of learning requires that the student gain an awareness that "different communities have different knowledge-building practices" (Goodyear and Zenios, 2007: 355). This case was famously made by C. P. Snow in "Two Cultures" (2013[1956]). The dialogic crossroads of a legacy of selves once included the strategies of Hannibal, the philosophy of Epictetus, and the science of Archimedes - and once gave students a variety of personages to measure themselves against; a variety of contexts, scenarios, and systems to reflect on. Today, this has ceded, in the best case scenario (and where it is nuanced), to a Bakhtinian understanding of learning as extending beyond a single mind to include a composite of voices (1984). A project-based dialogic course in grant writing has the potential to speak to this by modeling higher-order inter/intra-subjective negotiation. Students are encouraged to become self-directed in a dialogic context set up for a specific purpose (to do, explore, create...). Students not accustomed to being self-directed can in this way gain further awareness of how to learn how to solve problems in different contexts where the correct answer is not known: organically interacting through inquiry. Teachers also benefit from the self-reflective environment, gaining opportunities to "ripen on the job" and unlearn as well as learn (Anderson, 2016: 23). Any leaps of faith become replaced by the continuous, relational nature of knowledge acquisition and assembly. This is also a lesson in symmathesy, which through its attention to learning together also teaches the interconnected nature of life. Ideally we are learning to lead this, together. 


\section{REFERENCES}

Anderson, M. (2016). Harold C. Conklin: the joy of ethnography - from eye to ear to mouth to nose to hand, and beyond to within and without. In M. M. Snipes \& F. A. Salamone (eds.), Passing the torch: mentoring the next generation (pp. 17-37). Cambridge Scholars Publishing.

Anderson, V., Rabello, R., Wass, R., Golding, C., Rangi, A., Eteuati, E., Bristowe, Z., \& Waller, A. (2020). Good teaching as care in higher education. Higher Education, 79(1), 1-19.

Bakhtin, M. M. (1984). Problems of Dostoevsky's Poetics. Caryl Emerson (trans., ed.). Minneapolis, London: University of Minnesota Press.

Bateson, N. (2015). Symmathesy: a word in progress. Norabateson (3 November 2015). Accessed at https://norabateson.wordpress.com/2015/11/03/ symmathesy-a-word-in-progress. [08/20/2019]

Bateson, N. (2016). Small arcs of larger circles: framing through other patterns. Charmouth, UK: Triarchy Press.

Beaty, L., Cousin, G., \& Hodgson, V. (2010). Revisiting the e-quality in networked learning manifesto. In L. Dirckinck-Holmfeld et al. (eds.), Proceedings of the 7th international conference on networked learning (pp. 585-592). Networked Learning Conference.

Beaty, L., Hodgson, V., Mann, S., \& McConnell, D. (2002). Understanding the implications of networked learning for higher education. Accessed at http://csalt.lancs.ac.uk/esrc/manifesto.pdf. [08/03/2019]

Bruni, N. (2002). The crisis of visilibity: ethical dilemmas of autoethnographic research. Qualitative Research Journal, 2(1), 24-33.

Butler, J. (2005). Giving an account of oneself. New York: Fordham UP.

Collins, M. P., \& Berge, Z. L. (1996). Facilitating interaction in computer mediated online courses. Proceedings of the FSU/AECT Conference on Distance Learning. June 20-23, Tallahassee, FL.

Damasio, A. (1994). Descartes' error: emotion, reason and the human brain. New York: Avon.

Denzin, N. K., \& Lincoln, Y. S. (2018). Introduction: the discipline and practice of qualitative research. In N. K. Denzin \& Y. S. Lincoln (eds.), The SAGE handbook of qualitative research (pp. 29-71). Thousand Oaks: SAGE Publications.

Dewey, J. (1902). The child and the curriculum. Chicago: University of Chicago Press.

Dewey, J. (1916). Democracy and education. New York: McMillan.

Dewey, J. (1938). Logic: the theory of inquiry. New York: Henry Holt \& Company. 
DiSalvo, B., Yip, J., Bonsignore, E., \& DiSalvo, C. (eds.). (2017). Participatory design for learning: perspectives from practice and research. Routledge.

Engelbart, D. (2002). Improving our ability to improve. Keynote Address, World Library Summit, April 23-26, 2002, Singapore. Republished for the IBM Co-Evolution Symposium September 24, 2003.

Fawns, T. (2019). Postdigital education in design and practice. Postdigital Science and Education, 1(1), 132-145.

Filipović, J. (2015). Transdisciplinary approach to language study. New York: Palgrave MacMillan.

Freire, P. (1970). Pedagogy of the oppressed. New York: Herder and Herder.

Giroux, H. (1992). Border crossings: cultural workers and the politics of education. Routledge.

Goetz, G. (pending). Pedagogy of extraneity: Cultural studies in a global information age. In S. Macura (Ed.), BELLS90 Proceedings (vol. 2). BELLS90.

Goodyear, P. (2001). Effective networked learning in higher education: notes and guidelines. Lancaster, UK: Lancaster University. Accessed at http://csalt. lancs.ac.uk/jisc/docs/guidelines_final.doc. [08/12/2019]

Goodyear, P., \& Zenios, M. (2007). Discussion, collaboration and epistemic fluency. British Journal of Educational Studies, 55(4), 351-368.

Goodyear, P., Jones, C., Asensio, M., Hodgson, V., \& Steeples, C. (2005). Networked learning in higher education: students' expectations and experiences. Higher Education, 50, 473-508.

Heifetz, R. A., \& Laurie, D. L. (2001[1997]). The work of leadership. Harvard Business Review, 35-47. Accessed at http://www.kwli.org/wp-content/ uploads/2015/01/Heifetz-Laurie-2001.pdf. [03/15/2020]

Hodgson, V. E., \& McConnell, D. (2018). The epistemic practice of networked learning. In M. Bajic et al. (Eds.), Proceedings of the 11th International Conference on Networked Learning 2018 (vol. 11, pp. 455-464). Networked Learning Conference.

Hodgson, V. E., \& McConnell, D. (2019). Networked learning and postdigital education. Postdigital Science and Education, 1(1), 43-64.

Huberman, A. M., \& Miles, M. B. (1998). Data management and analysis methods. In N. K. Denzin \& Y. S. Lincoln (Eds.), Collecting and interpreting qualitative materials (pp. 179-210). Thousand Oaks: Sage Publications.

Jackson, D. (2004). Networked learning communities. A paper prepared for the International Congress for School Effectiveness and Improvement. Building Bridges for Sustainable School Improvement. January 2004, Rotterdam, the Netherlands. http://www.leeds.ac.uk/educol/documents/155821.htm. Accessed 12 August 2019. 
BUILDING ENVIRONING CONDITIONS FOR SYMMATHESY ...

Jovanović, A. (2016). Waking up from the university dream: Intersection of educational ideologies and professional identity construction. Saarbrücken: Lambert Academic Publishing.

Jones, C. (2012). Networked learning, stepping beyond the net generation and digital natives. In L. Dirckinck-Holmfeld et al. (eds.), Exploring the theory, pedagogy and practice of networked learning (pp. 27-42). Springer.

Jones, C., \& Esnault, L. (2004). The metaphor of networks in learning: communities, collaboration and practice. Networked Learning 2004 Conference, Lancaster, UK. https://telearn.archives-ouvertes.fr/hal00190280/document. Accessed 12 March 2020.

Kezar, A. J., \& Holcombe, E. M. (2019). Barriers to organizational learning in a multi-institutional initiative. Higher Education, 1-20. https://doi. org/10.1007/s10734-019-00459-4

Kinchloe, J. L., McLaren, P., Steinberg, S. R., \& Monzó, L. D. (2018). Critical pedagogy and qualitative research: advancing the bricolage. In N. K. Denzin \& Y. S. Lincoln (eds.), The SAGE handbook of qualitative research (pp. 418-465). Thousand Oaks: SAGE Publications.

Klein, S. B. (2002). Learning: principles and applications (4 ${ }^{\text {th }}$ ed.). New York: McGraw-Hill.

Knowles, M. S. (1984). Andragogy in action: applying modern principles of adult learning. San Francisco: Jossey-Bass.

Kolb, D. A., Rubin, I. M., \& McIntyre, J. M. (1974). Organizational psychology: a book of readings ( $2^{\text {nd }}$ ed.). Englewood Cliffs: Prentice-Hall.

Krakauer, D. (2016). Complexity and stupidity. Sam Harris Podcast Transcript (13 November 2016).Accessed at https://samharris.org/complexity-stupidity. [03/12/2020]

Kvale, S. (2007). Doing interviews. Thousand Oaks: Sage Publications.

Lave, J., \& Wenger, E. (1991). Situated learning: legitimate peripheral participation. Cambridge University Press.

Levinsen, K. T., \& Nielsen, J. (2012). Innovating design for learning in the networked society. In L. Dircknick-Holmfeld et al. (eds.), Exploring the theory, pedagogy and practice of networked learning (pp. 237-256). Springer.

Levy, P. (2004). A methodological framework for practice-based research in networked learning. In P. Goodyear et al. (eds.), Advances in research on networked learning (pp. 43-66). Boston: Kluwer Academic Publishers.

Lewin, K. (1946). Action research and minority problems. Journal of Social Issues, 2(4), 34-46.

Lissack, M. R. (2000). Knowledge management redux: reframing a consulting fad into practical tool. Emergence, 2(3), 78-89. 
Markauskaite, L., \& Goodyear, P. (2017). Epistemic fluency and professional education. Springer.

Mascolo, M. F., \& Fischer, K. W. (2005). Constructivist theories. In B. Hopkins et al. (eds.), Cambridge encyclopedia of child development (pp. 49-63). Cambridge: Cambridge University Press.

Morin, E. (2008[2004]). La Méthode (vol. 6). Paris: Éditions du Seuil.

Mousten, B., Vandepitte, S., Arno, E., \& Maylath, B. (2018). Preface. In B. Mousten et al. (eds.), Multilingual writing and pedagogical cooperation in virtual learning environments (pp. $\mathrm{xv}-\mathrm{xxi}$ ). Hershey, PA: IGI Global.

Murphy, M. S. (2013). Considering happiness and caring: a conversation with Nel Noddings. Teaching and Teacher Education, 34, 184-188.

Nielsen, J. L., \& Danielsen, O. (2012). Problem-oriented project studies: the role of the teacher as supervisor for the study group in its learning processes. In L. Dircknick-Holmfeld, V. Hodgson, \& D. McConnell (eds.), Exploring the theory, pedagogy and practice of networked learning (pp. 257-272). Springer.

Noddings, N. (2012). The caring relation in teaching. Oxford Review of Education, $38(6), 771-781$.

Norman, D. (2011). Living with complexity. Cambridge/London: MIT Press.

Online Learning Consortium. (2017). The Distance Education Enrollment Report 2017. Digital Learning Compass. Accessed at https:// onlinelearningconsortium.org/read/digital-learning-compass-distanceeducation-enrollment-report-2017. [12/03/2020]

Paavola, S., Lipponen, L., \& Hakkarainen, K. (2004). Models of innovative knowledge communities and three metaphors of learning. Review of Educational Research, 74(4), 557-576.

Perriton, L., \& Reynolds, M. (2014). 'Here be dragons': approaching difficult group issues in networked learning. In V. Hodgson et al. (2ds.), The design, theory and practice of networked learning (pp. 109-126). Springer.

Plato. (1967a). Meno. In Plato in Twelve Volumes (vol. 3). W. R. M. Lamb (Trans.). Cambridge, MA: Harvard UP.

Plato. (1967b). Protagoras. In Plato in Twelve Volumes (vol. 3). W. R. M. Lamb (Trans.). Cambridge, MA: Harvard UP.

Reed-Danahay, D. (1997). Auto/ethnography: rewriting the self and the social. New York: Bloomsbury Academic.

Reynolds, M. (2011). Reflective practice: origins and interpretations. Action Learning: Research and Practice, 8(1), 5-13.

Ricoeur, P. (1991). A Ricoeur reader: reflection and imagination. Mario J. Valdes (ed.). Toronto: University of Toronto Press. 
Ross, W. D. (1952). The Works of Aristotle, XII Selected Fragments. Oxford: Clarendon Press.

Schön, D. (1983). The reflective practitioner: how professionals think in action. London: Maurice Temple Smith.

Schön, D. (1985). The design studio. Cambridge/London: MIT and RIBA Building Industry Trust.

Snow, C. P. (2013[1956]). The two cultures. New Statesman (6 October, 1956), 413-414. Accessed at http://www.newstatesman.com/culturalcapital/2013/01/c-p-snow-two-cultures. [08/20/2019]

Sorensen, E. K. (2010). Democratic collaborative dialogue and negotiation of meaning in digital teaching and learning environments: reflections. In L. Dirckinck-Holmfeld et al. (Eds.), Proceedings of the 7th International Conference on Networked Learning 2010 (pp. 566-573). Accessed at https://pdfs.semanticscholar.org/a172/6330913d26831de1547224f3da432 0a90b3a.pdf. [08/20/2019]

Spry, T. (2018). Autoethnography and the Other: performative embodiment and a bid for utopia. In N. K. Denzin \& Y. S. Lincoln (eds.), The SAGE handbook of qualitative research (pp. 1090-1128). Thousand Oaks: SAGE Publications.

Stark, D. (2001). Ambiguous assets for uncertain environments: heterarchy in postsocialist firms. In P. Dimaggio (ed.), The twenty-first century firm: changing economic organization in international perspective (pp. 69104). Princeton, NJ: Princeton UP.

Stiegler, B. (2011) Distrust of the pharmacology of transformational technologies. In T. B. Zülsdorf et al. (eds.), Quantum Engagements (pp. 27-39). IOS Press.

Vivian, P., \& Hormann, S. (2013). Organizational trauma and healing. North Charleston, CV: CreateSpace.

Vygotsky, L. S. (1987). The collected works of L. S. Vygotsky (vol. 1). R. W. Rieber \& A. S. Carton (eds.). New York/London: Plenum Press.

Wells, G. (1999). Dialogic inquiry towards a sociocultural practice and theory of education. Cambridge University Press.

Wood, D. (1998[1986]). Aspects of teaching and learning. In M. Woodhead et al. (eds.), Cultural worlds of early childhood (pp. 157-177). Routledge. 


\title{
Greta Goetz
}

Ana Jovanović

\section{KREIRANJE SIGURNOG OKRUŽENJA ZA UMREŽENO PROJEKTNO UČENJE}

\begin{abstract}
Sažetak
U ovom radu istražujemo okolnosti u kojima nastavnici i studenti, po prvi put uključeni u projekat umreženog učenja, uspevaju da prevaziđu izazove vlastitih uvreženih obrazovnih očekivanja kako bi bili voljni da iskoriste mogućnosti novog obrazovnog iskustva. Ova spremnost podrazumeva volju za vežbu u simateziji (Bateson, 2015), tj. „zajedničkom učenju“ koje uključuje nove osobe, okolnosti, alate, ali i epistemološka uverenja. Vodeći se postulatima kvalitativnog istraživačkog pristupa, analiziramo okolnosti u kojima je sproveden kurs umreženog učenja, a koji je nastao u okviru saradnje na Trans-Atlantskom i Pacifičkom Projektu. Na osnovu analize dubinskih intervjua, koji su realizovani sa studentima učesnicima kursa, i autoetnografskih promišljanja, kritički procenjujemo uključenost svih aktera, uticaj njihovih uverenja, očekivanja i specifične epistemološke ideologije. Umreženo učenje, kao novo iskustvo koje ima potencijal da aktivnosti visokog obrazovanja uskladi s kompleksnošću stvarnog života, nameće neuobičajene zahteve na njegove nosioce, a koji se odnose na spremnost za preuzimanje rizika, prihvatanje neizvesnosti, obavezu otvorenosti i empatije. Stoga prikaz ovog slučaja nije relevantan samo za istraživanja s fokusom na inovativne aspekte umreženog učenja, već može biti relevantan u okvirima kritičke pedagogije i pedagogije brižnosti koja teži da nadomesti nedostatke automatizovanog i neizvesnog digitalnog pejzaža.
\end{abstract}

Ključne reči umreženo učenje; kvalitativno istraživanje; akademska pismenost; dijaloško učenje; kritička pedagogija; refleksivna praksa; digitalno učenje; visoko obrazovanje. 